bryos donated by fertility clinic patients. He says he is leaving for "the possibility of carrying out my research with human ES cells with public support."

Others may follow. "I have had calls from four US companies to clarify the legal position in the UK and to make preliminary enquiries regarding what steps they would have to take to establish a satellite R\&D operation in the UK," Simon Best, chief executive officer of Ardana Bioscience in Edinburgh, told Nature Medicine. Best, who did not identify the companies, added that the calls "came to me in a personal capacity, given my previous role with Roslin and Geron, and my ongoing responsibility as chair of the US Biotechnology Industry Organization Bioethics Committee." Martin Edwards, chief executive officer of London-based ReNeuron agrees: "The climate in the UK is both more settled and more favorable towards stem cell research, providing the right safeguards are in place." The Roslin Institute is also expanding its research program on stem cells.

Nuclear transfer ban

The pronouncement on stem cell policy has overshadowed the impending ban on the use of SCNT. On 31 July, the House of Representatives banned human cloning for any purpose-whether for reproduction or to create therapeutic stem cells. Moreover, the ban would apply to private as well as government-funded work and would extend to the importation of any medical treatments derived from cloned human embryo cells. The action must be approved by the Senate and signed by Bush before it can become law.

The House action was condemned by a range of patient advocacy groups, scientific organizations and biomedical ethicists. "Congress has gone too far," says Arthur Caplan, director of the center for bioethics at the University of Pennsylvania. "While it may be that a [reproductive cloning] ban is justified, I am worried that most congressmen who voted on this don't know precisely what they banned."

To further complicate the debate, the researchers claiming to be pursuing human cloning work vowed to continue their efforts at a Washington, DC symposium 6-7 August sponsored by the National Academy of Sciences.

\section{Kass to lead ES bioethics panel}

President Bush has announced the creation of a council to oversee the scientific and ethical developments in the stem-cell debate and has chosen bioethicist Leon Kass, from the University of Chicago, to head it. Although a respected bioethicist, Kass is well known for his deeply conservative views about the bold new paths of modern medicine, including stem-cell research.

Not surprisingly, his selection as head of a national panel that will guide the gov-

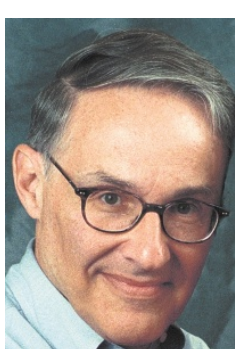

Leon Kass cloning research on much the same grounds."

Kass received his BS degree in biology and his medical degree from the University of Chicago in the early 1960s. He earned a PhD in biochemistry from Harvard University in 1967. He advises numerous ethical groups and is a founding fellow of the Hastings Center, a bioethics think tank outside New York City. He has published numerous articles on bioethics, social thought, science and human affairs, including such titles as "What ernment's oversight of stemcell research is a source of anxiety among those who support the work. "He is a thoughtful physician who has been interested in bioethics for thirty years; I like him and respect him," says Arthur Caplan, director of the center for bioethics at the University of Pennsylvania. "But he holds deeply conservative views about stem-cell research. Twenty years ago, he argued against the use of in vitro fertilizationhe felt it was unnatural to make kids in dishes. He argues against cloning, stem-cell research and therapeutic
Price the Perfect Baby?" and "Babies by Means of In Vitro Fertilization: Unethical Experiments on the Unborn?" He is outspoken in his opposition to human cloning, and wrote: "Even if human cloning is rarely undertaken, a society in which it is tolerated is no longer the same societyany more than is a society that permits incest or cannibalism or slavery on even a small scale. It is a society that has forgotten how to shudder, that rationalizes away the abominable."

Marlene Cimons, Washington, DC
Severino Antinori, an Italian fertility doctor, and Panayiotis Zavos of Kentucky, told an NAS panel that they planned to implant cloned human embryos in 200 women volunteers in the coming months. They are acting outside the system of scientific review that applies to scientific research, so the validity of their claims cannot be assessed. The response from researchers who have cloned animals was a dramatic warning that such experiments would likely produce deformed offspring. "Even clones that survive to birth often have severe abnormalities and die [prematurely] later," said Rudolf Jaenisch, a biologist and cloning expert at the Massachusetts Institute of Technology's Whitehead Institute. The NAS will issue a report on cloning in late September.

Marlene Cimons, Washington, DC

\section{Lindquist to direct Whitehead}

Protein biologist Susan Lindquist has been appointed the first woman director of the Whitehead Institute for Biomedical Research. Hers is the third appointment of a woman to a high-profile academic position this year (Nature Med., 7, 646; 2001) and is particularly poignant because the Whitehead Institute is the biomedical affiliate of the

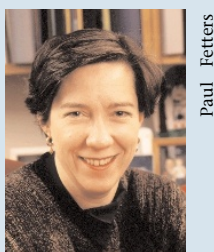

Susan Lindquist
Massachusetts

Institute of Technology (MIT), which was engulfed by gender discrimination issues in 1999.

MIT officials produced a frank report on the treatment of women faculty that triggered similar soul searching at several major research institutions, including Yale, the University of California system and University of Arizona.

Fellow biologist Nancy Hopkins, who spearheaded the landmark study of discrimination against female MIT faculty, called the Lindquist appointment a "milestone. It's not just that she's a woman, she's an outstanding scientist," Hopkins said. "It sends a message to the nation."

Lindquist's interdisciplinary research focuses on the interaction between protein folding, biology and environment. She has contributed to the understanding of how prions pass on genetic traits independent of genetic material and is also exploring the effect of heat-shock proteins on development and inheritance. She takes up the post next month.

Tinker Ready, Boston 